\title{
Vyhodnocení dotazníkového šetření pomocí korespondenční analýzy
}

\author{
Julie POLÁČKOVÁ, Andrea JINDROVÁ, Czech University of Life Sciences Prague ${ }^{\mathrm{i}}$
}

\begin{abstract}
The article is focused on the evaluation of a questionnaire survey. The aim was to determine whether the creation of interactive manuals, which monitor working in statistical software, helps to make education processes effective. For a clear evaluation and presentation of the pilot survey a method of correspondence analysis was chosen. The correspondence analysis is a multivariate graphical technique for representing information in a two-way contingency table. Analysis outputs indicate that these manuals are an effective way of teaching how to work in statistical software. This conclusion was confirmed primarily by less skilful students.
\end{abstract}

\section{Keywords}

Categorical data analysis, correspondence analysis, innovative teaching, interactive presentation, questionnaire survey analysis.

\section{JEL Classification: C49, C83}

\footnotetext{
${ }^{\text {i }}$ Department of Statistics, Faculty of Economics and Management, Czech University of Life Sciences, Kamýcká 129,16521 Prague 6-Suchdol, Czech Republic.

polackova@pef.czu.cz (corresponding author)

This research was supported by the Science Foundation (IGA) of the Czech University of Life Sciences under the project no. 200911170007.
}

\section{1. Úvod}

Vytvoření kvalitní studijní opory představuje metodický aparát, který výrazně zefektivní výuku statistických předmětů využívajících statistické programy. Nejen jazyková bariéra, ale i technická náročnost některých programů s sebou prrináší potřebu zhotovení názorných návodů. $\mathrm{V}$ rámci zefektivnění výuky statistických předmětů, především výuky práce ve statistických systémech, jsou vytvářeny názorné návody (instruktážní prezentace), které demonstrují postupy práce ve statistických programech. Záměrem autorů těchto prezentací je usnadnit a přiblížit studentům ovládání těchto systémů a orientaci v nich. Pomocí realizovaného pilotního dotazníkového šetření je zkoumáno, zda jsou tyto prezentace studenty vnímány jako kvalitní studijní podpora, má-li jejich využívání vliv na zefektivnění domácí př́pravy a zda studenti dokáží na základě těchto manuálů pochopit postupy tvorby statistických analýz.

Cílem prríspěvku je analyzovat získané informace z dotazníkového šetrení pomocí korespondenční analýzy. První část př́spěvku je zaměřena na zkoumání existence spojitostí mezi vztahem studentů ke studiu a jejich názorem na užitečnost realizovaných prezentací. V druhé části je zkoumán vztah mezi zkušenostmi studentů s informačními technologiemi a jejich názorem na zefektivnění domácí přípravy. Je možné předpokládat, že prospěšnost realizovaných návodů ocení především uživatelé s nižší počítačovou gramotností, kteří vykazují větší problémy s orientací v počítačových systémech.

\section{Použitá metodika}

K analýze dotazníkového šetření byly využity nástroje korespondenční analýzy dat. Tato analýza představuje 
populární grafickou techniku využívanou $\mathrm{k}$ analýze vztahů mezi kategoriemi jedné či více proměnných v kontingenčních tabulkách. Pomocí nástrojů korespondenční analýzy je možné popsat asociace nominálních či ordinálních proměnných a získat grafické znázornění souvislostí ve vícerozměrném prostoru (více Ramos a Carvalho, 2010). Beh (2010) spatřuje největší výhodu této metody právě $\mathrm{v}$ její schopnosti graficky znázornit propojenost jednotlivých kategorií. Rencher (2002) zdůrazňuje, že základem vytváření subjektivní (korespondenční) mapy jsou tzv. latentní veličiny. Polohy bodů $\mathrm{v}$ subjektivní mapě prímo vyjadřují asociaci; vzdálenosti mezi body (neboli vzdálenost řádkových a sloupcových profilů) je možné přenést do dvojrozměrné euklidovské roviny, ve které body odpovídají jednotlivým kategoriím.

Hebák a kol. (2007) dodává, že korespondenční analýza zobrazuje korespondence kategorií jednotlivých proměnných a poskytuje společný obraz řádkových i sloupcových kategorií ve stejných dimenzích. Na rozdíl od většiny ostatních vícerozměrných metod umožňuje korespondenční analýza zpracování kategorizovaných nemetrických dat i nelineárních vztahů. Představuje obdobu faktorové analýzy, místo faktorů je však sledován vliv jednotlivých kategorií, jejich vzájemná podobnost či asociace s kategoriemi ostatních proměnných (Rencher, 2002).

Cílem korespondenční analýzy je dle Hebáka a kol. (2007) ... redukce mnohorozmérného prostoru vektorů rádkových a sloupcových profilů pri maximálním zachováni informace obsažené $v$ pưvodnich datech. V subjektivním mapování bývá nejčastěji využíváno dvojrozměrného (roviny) či maximálně trojrozměrného zobrazení vzdáleností v euklidovském prostoru. Častěji než euklidovská vzdálenost se využíá Pearsonova statistika chí-kvadrát. Blízké rádkové body indikují řádky, které mají podobné profily v celém řádku, blízké sloupcové body indikují sloupce s podobnými profily směrem dolů přes všechny řádky. A řádkové body, které jsou v těsné blízkosti sloupcových bodů, představují kombinace, které se objeví častěji, než by se očekávalo u nezávislého modelu, ve kterém řádkové kategorie nejsou vztaženy ke sloupcovým (Meloun a kol., 2005).

Rozptýlenost bodů je možné posuzovat dle ukazatele inercie, který odpovídá váženému průměru chíkvadrát vzdáleností rádkových (respektive sloupcových) profilů od svého průměru (Meloun a kol., 2005). Singulární hodnota a inercie odpovídá vlastnímu číslu v analýze hlavních komponent; představuje míru variability mezi profily vysvětlenou danou dimenzí řešení nebo danou kategorií. Podle toho určíme potřebný počet dimenzí. Odlišnost profilů, měřená pomocí míry založené na chí-kvadrát statistice, je to, co se projeví v grafu jako vzdálenost mezi položkami stejné proměnné. Vzdálenost mezi položkami různých proměnných jsou obrazy standardizovaných reziduí na průsečíku položek.

Jako hlavní předpoklad pro použití korespondenční analýzy uvádí autoři Meloun a kol. (2005) kromě porovnatelnosti objektů také úplnost datové matice. Řešení vychází z matice standardizovaných reziduí, kterou je možné vytvořit na základě některé z normalizačních metod. Výběr normalizační metody závisí na preferencích výzkumníka. Při preferencích vztahů mezi řádkovými kategoriemi je využívána analýza řádkových profilů, při upřednostnění sloupcových kategorií vycházíme $\mathrm{z}$ analýzy sloupcových profilů. Kombinací těchto dvou analýz je metoda symetrická, která umožňuje vzájemné srovnání řádkové a sloupcové kategorie. Tato metoda je preferována, pokud je cílem vytvořit bodový graf sloupcových a řádkových profilů (symetrické mapy) (Řezanková, 2007).

Pilotního dotazníkového šetření se zúčastnili studenti 4. ročníku oboru Informatika (INFO) a studenti 2. ročníku oboru Podnikání a administrativa $(\mathrm{PaA})$, kteří využívají statistický software $\mathrm{v}$ rámci výuky statistických předmětů. Distribuce a sběr dotazníků probíhaly dvojí formou. U oboru INFO byly dotazníky vyplňovány elektronicky $\mathrm{v}$ př́slušném kurzu vytvořeném v systému Moodle. U oboru PaA byly dotazníky předány studentům $\mathrm{k}$ vyplnění př́mo $\mathrm{v}$ jednotlivých cvičeních $\mathrm{v}$ papírové podobě.

Ke zpracování dotazníkového šetření byl využit statistický software SPSS Statistics 17.0 for Windows, který představuje moderní systém pro popis a vizualizaci datových vztahů. Výhodnou daného softwaru při zpracování dat z dotazníkových šetření je existence tzv. codebooku, který obsahuje informace o datové matici (názvy a popisy proměnných, popisy hodnot, chybějící hodnoty), čímž uživateli usnadní následnou realizaci statistických analýz.

\section{Vlastní zpracování a diskuze}

Pomocí realizovaného pilotního dotazníkového šetření byla zjišt'ována efektivita vytvořených interaktivních prezentací. Cílem bylo získání poznatků o tom, zda vytvoření komplexního studijního materiálu demonstrujícího práci ve statistickém softwaru je pro studenty př́nosné a přispěje $\mathrm{k}$ jejich lepší a rychlejší orientaci v daném systému.

\subsection{Analýza vztahu studentů ke studiu a jejich názoru na instruktážní prezentace}

Nejprve byla analyzována závislost vztahu studentů ke studiu a jejich názoru na tvrzení, že jim interaktivní prezentace (IP) umožnily překonat potíže s orientací ve statistickém systému. 
Tabulka 1 zachycuje vstupní absolutní četnosti. Počet kategorií u obou proměnných je roven třem, z čehož je možné odvodit maximální počet dimenzí použitých $\mathrm{v}$ proceduře. Maximální počet dimenzí představuje nejnižší počet kategorií u jednotlivých proměnných snížený o jednotku. Počet dimenzí bude tedy roven dvěma.

Ze souhrnné tabulky korespondenční analýzy vyplynulo, že první dimenze zachycuje 89 \% celkové informace - variability (inerce), druhá dimenze vysvětluje zbývajících $11 \%$ informace.

Ukazatel zátěží (Mass), uvedený v tabulce 2, označuje řádkovou zátěž, která představuje procentuální podíl informace $\mathrm{z}$ celé tabulky $\mathrm{v}$ dané kategorii. Tuto zátěž získáme jako poměr řádkové či sloupcové okrajové četnosti $\left(n_{i+}, n_{+j}\right)$ a celkové četnosti tabulky (n). Nejvyšší podíl řádkové proměnné nalezneme u třetí kategorie, která zastupuje výrok určitě souhlasím. Kategorie pripravuji se pouze v rámci zadaných projektů představuje nejvyšší podíl sloupcové proměnné. Následující dva sloupce (Score in Dimension) zachycují skóre v prvních dvou rozměrech.
Ukazatel inerce (Inertia) představuje podíl celkové informace na profilu čili na dotyčném bodu. Tato charakteristika je nezávislá na počtu dimenzí.

Z tabulky 2 je patrné, že první hlavní komponenta $\mathrm{v}$ řádkovém profilu dělí studenty na ty, kteř́ s tvrzením, že jim IP umožnily překonat potíže s orientací ve statistickém systému, souhlasí, a ty, co jsou neutrální, tedy souhlasí pouze částečně. Druhá hlavní komponenta rozděluje studenty, kterým interaktivní prezentace umožnily překonat potíže, dle míry souhlasu.

První hlavní komponenta ve sloupcovém profilu (viz tabulka 3) odděluje studenty, kteří se na studium připravují, od těch, kteří preferují tzv. cestu nejmenšího odporu. Druhá hlavní komponenta dělí studenty dle míry zaujetí studiem.

K zobrazení korespondenční mapy, která zachycuje grafické znázornění sloupcových i řádkových kategorií, byl zvolen symetrický model. Na rozdíl od asymetrických map, ve kterých docházelo k přehuštění prostoru a celkové nečitelnosti modelu, jsou v symetrických mapách řádkové a sloupcové body rozptýleny rovnoměrně.

Tabulka 1 Korespondenční tabulka absolutních četností

\begin{tabular}{|l|c|c|c|c|}
\hline \multirow{2}{*}{$\begin{array}{l}\text { IP mi umožnily překonat } \\
\text { potíze s orientací } \\
\text { ve statistickém systému }\end{array}$} & \multicolumn{5}{|c|}{ Jaký je Váš vztah ke studiu? Připravuji se... } \\
\cline { 2 - 5 } & na zajímavé předměty & v rámci projektů & v minimální možné míře & Active Margin \\
\hline částečně souhlasím & 9 & 18 & 6 & 33 \\
\hline spíše souhlasím & 7 & 17 & 2 & 26 \\
\hline určitě souhlasím & 14 & 40 & 7 & 61 \\
\hline Active Margin & 30 & 75 & 15 & 120 \\
\hline
\end{tabular}

Tabulka 2 Tabulka řádkových zátěží

\begin{tabular}{|c|c|c|c|c|c|c|c|c|c|}
\hline \multirow{3}{*}{$\begin{array}{l}\text { IP mi umožnily překonat } \\
\text { potíže s orientací } \\
\text { ve statistickém systému }\end{array}$} & \multirow[b]{3}{*}{ Mass } & \multirow{2}{*}{\multicolumn{2}{|c|}{ Score in Dimension }} & \multirow[b]{3}{*}{ Inertia } & \multicolumn{5}{|c|}{ Contribution } \\
\hline & & & & & \multicolumn{2}{|c|}{$\begin{array}{l}\text { Of Point to Inertia } \\
\text { of Dimension }\end{array}$} & \multicolumn{3}{|c|}{$\begin{array}{l}\text { Of Dimension to Inertia } \\
\text { of Point }\end{array}$} \\
\hline & & 1 & 2 & & 1 & 2 & 1 & 2 & Total \\
\hline částečně souhlasím & 0,275 & $-0,553$ & 0,084 & 0,010 & 0,681 & 0,044 & 0,992 & 0,008 & 1,000 \\
\hline spíše souhlasím & 0,217 & 0,366 & 0,331 & 0,005 & 0,235 & 0,548 & 0,777 & 0,223 & 1,000 \\
\hline určitě souhlasím & 0,508 & 0,143 & $-0,186$ & 0,002 & 0,084 & 0,407 & 0,626 & 0,374 & 1,000 \\
\hline Active Total & 1,000 & & & 0,017 & 1,000 & 1,000 & & & \\
\hline
\end{tabular}

Tabulka 3 Tabulka sloupcových zátěži

\begin{tabular}{|c|c|c|c|c|c|c|c|c|c|}
\hline \multirow{3}{*}{$\begin{array}{l}\text { Jaký je Váš vztah ke } \\
\text { studiu? Připravuji se... }\end{array}$} & \multirow[b]{3}{*}{ Mass } & \multirow{2}{*}{\multicolumn{2}{|c|}{ Score in Dimension }} & \multirow[b]{3}{*}{ Inertia } & \multicolumn{5}{|c|}{ Contribution } \\
\hline & & & & & \multicolumn{2}{|c|}{$\begin{array}{c}\text { Of Point to Inertia } \\
\text { of Dimension }\end{array}$} & \multicolumn{3}{|c|}{$\begin{array}{c}\text { Of Dimension to Inertia } \\
\text { of Point }\end{array}$} \\
\hline & & 1 & 2 & & 1 & 2 & 1 & 2 & Total \\
\hline na zajímavé předměty & 0,250 & $-0,111$ & 0,355 & 0,002 & 0,025 & 0,725 & 0,217 & 0,783 & 1,000 \\
\hline v rámci projektů & 0,625 & 0,215 & $-0,099$ & 0,004 & 0,235 & 0,140 & 0,931 & 0,069 & 1,000 \\
\hline v minimální možné míře & 0,125 & $-0,855$ & $-0,216$ & 0,012 & 0,740 & 0,135 & 0,978 & 0,022 & 1,000 \\
\hline Active Total & 1,000 & & & 0,017 & 1,000 & 1,000 & & & \\
\hline
\end{tabular}




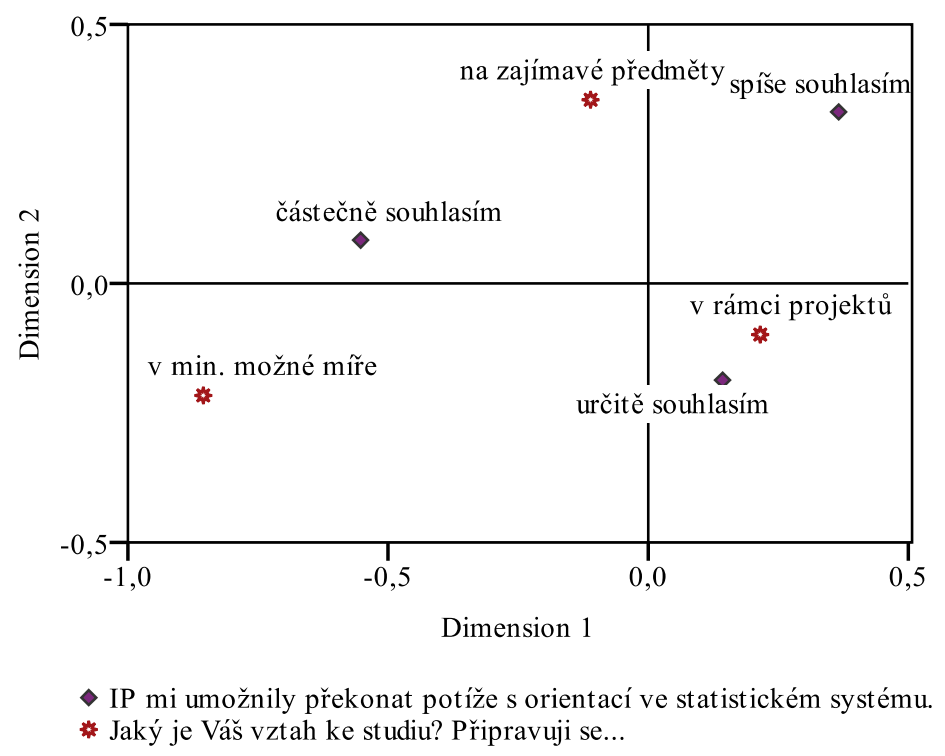

Obrázek 1 Symetrická korespondenční mapa sloupcových a řádkových profilů

Výstupy korespondenční analýzy zahrnují názorné grafy, které ilustrují vztahy mezi jednotlivými kategoriemi a proměnnými. Následující bodový graf zachycuje řádkové a sloupcové skóre pro dvojdimenzionální řešení. Využití symetrické normalizace zjednodušuje prozkoumání vztahů mezi jednotlivými kategoriemi daných proměnných.

Obrázek 1 zachycuje vzájemné vztahy zkoumaných kategorií. $Z$ grafu jsou patrné tři oddělené skupiny kategorií. Studenti, kteří se připravují především na zajímavé předměty, spíše souhlasí s tvrzením, že jim IP umožnily překonat potíže s orientací ve statistickém systému. Studenti, kteří se připravují pouze v rámci zadaných projektů, s daným tvrzením souhlasí určitě, jelikož jim IP z pravidla usnadní vytvoření projektu. Naopak studenti, kteří se na výuku připravují v minimální možné míře, s tvrzením souhlasí pouze částečně, jelikož raději zvolí rychlejší a méně podrobné formy nápovědy.

\subsection{Analýza vztahu mezi IT zkušenostmi a názo- rem na zefektivnění domácí př́pravy}

Dále byl zkoumáno, zda existuje vztah mezi zkušenostmi studenti̊ $\mathrm{s}$ informačními technologiemi a názorem na zefektivnění domácí př́pravy. Lze předpokládat, že výhody realizovaných prezentací ocení především studenti s nižší zkušeností s IT. Absolutní četnosti jednotlivých kategorií jsou uvedeny v tabulce 4.

Stejně jako v první analýze, i zde byly využity pouze dvě dimenze. Ze souhrnné tabulky korespondenční analýzy vyplynulo, že první dimenze zachycuje $88 \%$ celkové informace a druhá dimenze vysvětluje zbývajících $12 \%$ informace.

První hlavní komponenta $\mathrm{v}$ řádkovém profilu dělí studenty na ty, kteří souhlasí s tvrzením, že IP zefektivnily domácí prípravu, zbývající studenti jsou neutrální, tedy souhlasí pouze částečně. Druhá hlavní komponenta rozděluje studenty dle míry souhlasu s výrokem, že využití interaktivních prezentací zefektivnilo jejich domácí príípravu (viz tabulka 5).

Z tabulky 6 je patrné, že první hlavní komponenta ve sloupcovém profilu dělí studenty dle zkušenosti s informačními technologiemi na uživatele a experty (administrátory apod.). Druhá hlavní komponenta pak rozděluje studenty dle zkušenosti na mírně, středně a velmi pokročilé uživatele.

Vzájemné vztahy zkoumaných kategorií zachycuje obrázek 2. Z grafu již nejsou patrné tak výrazně

Tabulka 4 Korespondenční tabulka absolutních četností

\begin{tabular}{|l|c|c|c|c|c|}
\hline \multirow{2}{*}{$\begin{array}{l}\text { IP zefektivnily domácí } \\
\text { prípravu }\end{array}$} & \multicolumn{5}{|c|}{ zkušenosti s IT } \\
\cline { 2 - 6 } & $\begin{array}{c}\text { mírně pokročilý } \\
\text { uživatel }\end{array}$ & $\begin{array}{c}\text { středně pokročilý } \\
\text { uživatel }\end{array}$ & $\begin{array}{c}\text { velmi pokročilý } \\
\text { uživatel }\end{array}$ & expert & Active Margin \\
\hline částečně souhlasím & 1 & 13 & 5 & 4 & 2 \\
\hline spíše souhlasím & 4 & 16 & 8 & 6 & 30 \\
\hline určitě souhlasím & 11 & 33 & 15 & 12 & 65 \\
\hline Active Margin & 16 & 62 & 28 & 118 \\
\hline
\end{tabular}




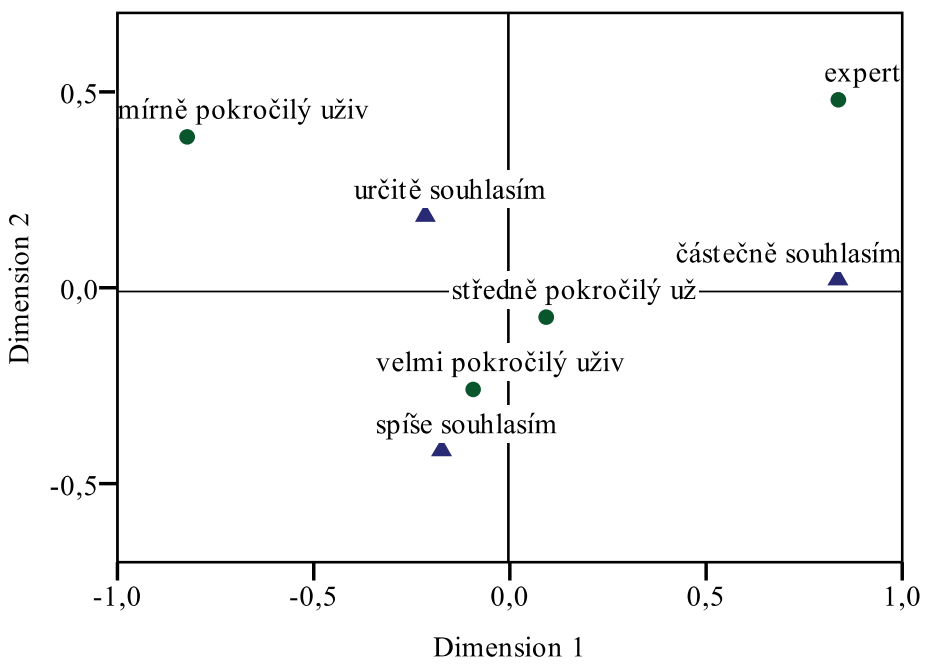

A Instruktážní prezentace zefektivnily domácí přípravu.

- Zkušenosti s informačními technologiemi.

Obrázek 2 Symetrická korespondenční mapa sloupcových a řádkových profilů

oddělené skupiny kategorií, jak tomu bylo v předchozím prrípadě. Obecně lze ale konstatovat, že čím je uživatel pokročilejší, tím méně zastává názor, že IP zatraktivnily jeho domácí přípravu. S daným tvrzením určitě souhlasí převážně méně pokročilí uživatelé. Velmi pokročilí uživatelé s tímto názorem souhlasí spíše a experti souhlasí pouze částečně.

Získané výsledky podporují záměry autorů instruktážních prezentací, kteří se zaměřili především na méně zkušené uživatele, kteří mají větší problémy s orientací ve složitých programových systémech. Pokročilí uživatelé či programátoři již pravděpodobně nemají s orientací v nových programech větší potíže, nebo si v případě potřeby naleznou potřebné informace ve zdrojích dostupných na internetu či $\mathrm{v}$ nápovědách.

\section{Závěr}

Z uvedených analýz vyplývá, že studenti, kteří se věnují domácí prrípravě intenzivněji, více oceňují existenci instruktážních prezentací, které jim pomáhají překonat problémy s orientací ve statistickém systému. Studenti s jejich pomocí snáze porozumí práci ve

Tabulka 5 Tabulka řádkových zátěží

\begin{tabular}{|c|c|c|c|c|c|c|c|c|c|}
\hline \multirow{3}{*}{$\begin{array}{l}\text { IP zefektivnily domácí } \\
\text { př́ípravu }\end{array}$} & & \multirow{2}{*}{\multicolumn{2}{|c|}{ Score in Dimension }} & & \multicolumn{5}{|c|}{ Contribution } \\
\hline & & & & & \multicolumn{2}{|c|}{$\begin{array}{l}\text { Of Point to Inertia } \\
\text { of Dimension }\end{array}$} & \multicolumn{3}{|c|}{$\begin{array}{c}\text { Of Dimension to Inertia } \\
\text { of Point }\end{array}$} \\
\hline & Mass & 1 & 2 & Inertia & 1 & 2 & 1 & 2 & Total \\
\hline částečně souhlasím & 0,195 & 0,836 & 0,021 & 0,023 & 0,804 & 0,001 & 1,000 & 0,000 & 1,000 \\
\hline spíše souhlasím & 0,254 & $-0,174$ & $-0,415$ & 0,004 & 0,045 & 0,700 & 0,323 & 0,677 & 1,000 \\
\hline určitě souhlasím & 0,551 & $-0,216$ & 0,184 & 0,006 & 0,151 & 0,298 & 0,789 & 0,211 & 1,000 \\
\hline Active Total & 1,000 & & & 0,033 & 1,000 & 1,000 & & & \\
\hline
\end{tabular}

Tabulka 6 Tabulka sloupcových zátěží

\begin{tabular}{|c|c|c|c|c|c|c|c|c|c|}
\hline \multirow{3}{*}{ zkušenosti s IT } & \multirow[b]{3}{*}{ Mass } & \multirow{2}{*}{\multicolumn{2}{|c|}{ Score in Dimension }} & \multirow[b]{3}{*}{ Inertia } & \multicolumn{5}{|c|}{ Contribution } \\
\hline & & & & & \multicolumn{2}{|c|}{$\begin{array}{l}\text { Of Point to Inertia } \\
\text { of Dimension }\end{array}$} & \multicolumn{3}{|c|}{$\begin{array}{l}\text { Of Dimension to Inertia } \\
\text { of Point }\end{array}$} \\
\hline & & 1 & 2 & & 1 & 2 & 1 & 2 & Total \\
\hline mírně pokročilý uživatel & 0,136 & $-0,822$ & 0,385 & 0,017 & 0,541 & 0,322 & 0,925 & 0,075 & 1,000 \\
\hline středně pokročilý uživatel & 0,525 & 0,093 & $-0,075$ & 0,001 & 0,027 & 0,047 & 0,805 & 0,195 & 1,000 \\
\hline velmi pokročilý uživatel & 0,237 & $-0,094$ & $-0,259$ & 0,001 & 0,012 & 0,256 & 0,262 & 0,738 & 1,000 \\
\hline expert & 0,102 & 0,837 & 0,480 & 0,014 & 0,420 & 0,375 & 0,892 & 0,108 & 1,000 \\
\hline Active Total & 1,000 & & & 0,033 & 1,000 & 1,000 & & & \\
\hline
\end{tabular}


statistických systémech. Využití těchto prezentací $\mathrm{v}$ rámci samostudia vede $\mathrm{k}$ celkovému zefektivnění domácí prŕípravy. Tento fakt je př́nosný nejen z pohledu studentů, ale i z hlediska pedagogů, kteří mají na hodinách výuky větší prostor pro výklad statistických metod a prezentaci jejich výstupů.

Dále bylo zjištěno, že méně pokročilí uživatelé informačních technologií spíše zastávají názor, že instruktážní prezentace zatraktivnily jejich domácí př́íravu. Naopak pokročilejší uživatelé počítače (experti) nemají s orientací v novém systémovém prostředí větší obtíže, a přestože existenci manuálů oceňují, není pro ně nezbytná. Tyto výsledky podporují cíle autorů IP, jejichž záměrem bylo směřovat pozornost především na méně zkušené uživatele informačních technologií, kteří mívají obecně větší problémy $\mathrm{s}$ orientací ve složitých programových systémech.

\section{Literatura}

BEH, E.J. (2010). Elliptical confidence regions for simple correspondence analysis. Journal of Statistical Planning and Inference 140: 2582-2588. http://dx.doi.org/10.1016/j.jspi.2010.03.018

HEBÁK, P., HUSTOPECKÝ, J., PECÁKOVÁ, I., PRŮŠA, M., ŘEZANKOVÁ, H., SVOBODOVÁ, A.,VLACH, P. (2007). Vícerozměrné statistické metody (3). Praha: Informatorium.

MELOUN, M., MILITKÝ, J., HILL, M. (2005). Počitačová analýza vícerozměrných dat v př́kladech. Praha: Academia.

RAMOS, M., CARVALHO, H. (2010). Perceptions of quantitative methods in higher education: mapping student profiles. Higher Education, published online: 25. July 2010. Dostupné na WWW: http://dx.doi.org/ 10.1007/s10734-010-9353-3.

RENCHER, A. (2002). Methods of Multivariate Analysis. New York: Wiley.

ŘEZANKOVÁ, H. (2007). Analýza dat z dotazníkového šetrení. Praha: Profesional Publishing. 